\title{
Slip Distribution and Seismic Moment of the 2010 and 1960 Chilean Earthquakes Inferred from Tsunami Waveforms and Coastal Geodetic Data
}

\author{
Yushiro FujII $^{1}$ and KenjI SATAKE ${ }^{2}$
}

\begin{abstract}
The slip distribution and seismic moment of the 2010 and 1960 Chilean earthquakes were estimated from tsunami and coastal geodetic data. These two earthquakes generated transoceanic tsunamis, and the waveforms were recorded around the Pacific Ocean. In addition, coseismic coastal uplift and subsidence were measured around the source areas. For the 27 February 2010 Maule earthquake, inversion of the tsunami waveforms recorded at nearby coastal tide gauge and Deep Ocean Assessment and Reporting of Tsunamis (DART) stations combined with coastal geodetic data suggest two asperities: a northern one beneath the coast of Constitucion and a southern one around the Arauco Peninsula. The total fault length is approximately $400 \mathrm{~km}$ with seismic moment of $1.7 \times 10^{22} \mathrm{Nm}$ (Mw 8.8). The offshore DART tsunami waveforms require fault slips beneath the coasts, but the exact locations are better estimated by coastal geodetic data. The 22 May 1960 earthquake produced very large, $\sim 30 \mathrm{~m}$, slip off Valdivia. Joint inversion of tsunami waveforms, at tide gauge stations in South America, with coastal geodetic and leveling data shows total fault length of $\sim 800 \mathrm{~km}$ and seismic moment of $7.2 \times 10^{22} \mathrm{Nm}$ (Mw 9.2). The seismic moment estimated from tsunami or joint inversion is similar to previous estimates from geodetic data, but much smaller than the results from seismic data analysis.
\end{abstract}

Key words: 2010 Maule earthquake, 1960 Valdivia earthquake, Chile tsunami, tsunami waveforms, geodetic data, joint inversion.

\section{Introduction}

Great $(M>8)$ or giant $(M>9)$ earthquakes have repeatedly occurred off the western coast of South America, where the Nazca Plate is subducting beneath the South American Plate with convergence speed of

1 International Institute of Seismology and Earthquake Engineering (IISEE), Building Research Institute (BRI), 1 Tachihara, Tsukuba, Ibaraki 305-0802, Japan. E-mail: fujii@ kenken.go.jp

2 Earthquake Research Institute (ERI), University of Tokyo, 1-1-1 Yayoi, Bunkyo-ku, Tokyo 113-0032, Japan. about $7.0 \mathrm{~cm} /$ year (Altamimi et al., 2007). Along the central Chilean coast, the 2010 Maule earthquake (M 8.8 ) is considered as a rerupture of the 1835 earthquake (MADARIAGA et al., 2010). The size of the 1835 earthquake was M 8-8.25 according to LoMNITZ (1970). Along the southern Chilean coast, where a giant earthquake (M 9.5) occurred around Valdivia in 1960, historical data show that great earthquakes have recurred with average interval of 120 years (LomNITZ, 1970). However, recent geological evidence of past tsunamis and coastal subsidence shows that the average recurrence interval of giant earthquake is about 300 years (CisTERnAs et al., 2005).

The Maule earthquake occurred on 27 February 2010 [06:34:14 UTC, 35.931 S, 72.784 W, 35 km, M 8.8 according to the US Geological Survey (USGS)] and generated a tsunami that caused significant damage on the Chilean coast. Coastal land-level changes were also reported by the field survey (FARIAs et al., 2010). Various source models of this earthquake have been proposed by using seismic waves (LAY et al., 2010; PuLIDo et al., 2011), global positioning system (GPS) data (Tong et al., 2010), GPS and interferometric synthetic aperture radar (InSAR) data (Delouis et al., 2010; VIGNY et al., 2011), or geodetic data and tsunami waveforms (LoRITo et al., 2011). Among them, VIGNY et al. (2011) compiled the slip distributions from the aforementioned studies and compared them with the observed GPS data. While these models all show that there were two large slip patches, or asperities, their locations vary. Some models (LAY et al., 2010; VIGNY et al., 2011) show that both asperities are offshore, while others show a more coastal location (Delouis et al., 2010; LoRITO et al., 2011).

The 1960 Chilean earthquake which occurred off the coast of southern Chile on 22 May is known as the largest earthquake ( $\mathrm{Mw}$ 9.5) of the 20th century 
(KAnAmORI, 1977). The length of the aftershock area extends approximately $900 \mathrm{~km}$ (Fig. 1). The earthquake also caused coastal uplift and subsidence as large as $5 \mathrm{~m}$ (Plafker, 1972; Plafker and Savage, 1970). The seismic moment estimated from free oscillation of the Earth is in the range 2.0-3.2 $\times$ $10^{23} \mathrm{Nm}$ (Mw 9.5-9.6) (Cifuentes and Silver, 1989; Kanamori and Anderson, 1975), but it is twice as large if the slow precursor event 15 min before the mainshock is included (KANAMORI and CIPAR, 1974). The seismic moment estimated from the coastal movement and leveling data is approximately $1.0 \times 10^{23} \mathrm{Nm}$ (Mw 9.3) (BARRIENTOS and WARD, 1990; MoRENo et al., 2009), about half of estimates from seismic data alone. This large discrepancy may be attributed to possible large slip or seismic moment offshore (BARRIENTOS and WARD, 1990).

If large slip occurs on offshore parts of the subduction interface, large seafloor deformation and tsunami waves should be produced. Indeed, these two earthquakes generated tsunamis that were recorded throughout the Pacific Ocean. We use tsunami waveforms recorded on coastal tide gauges and deep water pressure gauges to estimate the offshore slip. Slip beneath the coast or land produces coastal seafloor deformation, but does not contribute to tsunamis recorded at far distance. Coastal geodetic data on the other hand provide better control on slip amounts occurring beneath the coast or land. We therefore jointly use tsunami waveforms and coastal geodetic data to estimate the slip distribution across the land, coast, and offshore. In the 2010 earthquake, GPS measurements recorded horizontal motions, however we only used the vertical component of geodetic data, because tsunamis are generated from vertical seafloor movement. This restriction also ensures that similar data and the same method are used to estimate and compare the source size and the seismic moment of both the 2010 and 1960 earthquakes.

\section{Tsunamis from the Two Chilean Earthquakes}

\subsection{Trans-Pacific Tsunamis}

The 2010 tsunami was recorded at many tide gauge stations around the Pacific Ocean, as well as 25 tsunami sensors of the Deep Ocean Assessment and
Reporting of Tsunamis (DART) system operated by the National Oceanic and Atmospheric Administration (NOAA) and Hydrographic and Oceanographic Service of Chilean Navy (SHOA). In addition, 16 ocean-bottom pressure gauge stations on submarine cables around Japan recorded the tsunami. The tsunami amplitudes range from a few centimeters to several tens of centimeters (Fig. 2). The tsunami reached the Japanese coasts in approximately $23 \mathrm{~h}$ with heights up to $2 \mathrm{~m}$ (Iмai et al., 2010; Tsus et al., 2010). There were no casualties in Japan, but damage to floating materials such as aquafarming rafts was caused by water currents associated with the tsunami.

The 1960 earthquake also produced a large tsunami which affected the entire Pacific Ocean. The tsunami magnitude (Mt) was estimated as 9.4, the largest in history (ABE, 1979). The tsunami was recorded at many tide gauges around the Pacific Ocean (Berkman and Symons, 1964). The distribution of tsunami amplitudes (Fig. 3; positive values of zero-to-peak in the tsunami waveforms) shows that the far-field tsunami was largest in Japan, and also large on the west coast of USA, New Zealand, the Philippines, and Hawaii (Watanabe, 1972). The tsunami caused 61 deaths in Hawaii, 142 deaths in Japan, and 32 dead or missing in the Philippines (UNESCO/IOC, 2010). The large tsunami that propagated toward Japan was caused by several factors, including sphericity of the Earth, refraction due to large-scale bathymetry such as the East Pacific Rise (SATAKE, 1988), and the radiation pattern associated with the fault strike, which is often cited as a directivity effect (Ben-Menahem, 1971).

Discrepancies in observed and computed travel times for the trans-Pacific tsunami have been reported; For example, TANG et al. (2009) reported that the observed travel times in Hawaii from the 2007 Peru tsunami were 12 min later than predicted by the model. The observed tsunami arrival times of the 2010 Chilean tsunami at offshore GPS gauges and ocean-bottom pressure gauges (OBPG) in Japan were 30 min later compared with the predictions (КАTO et al., 2011; SATAKE et al., 2010). Computed tsunami waveforms from a simple rectangular fault model (Fig. 2) show that the synthetic waveforms and arrival times are similar to the observed ones at DART stations in the southeastern Pacific Ocean, but 


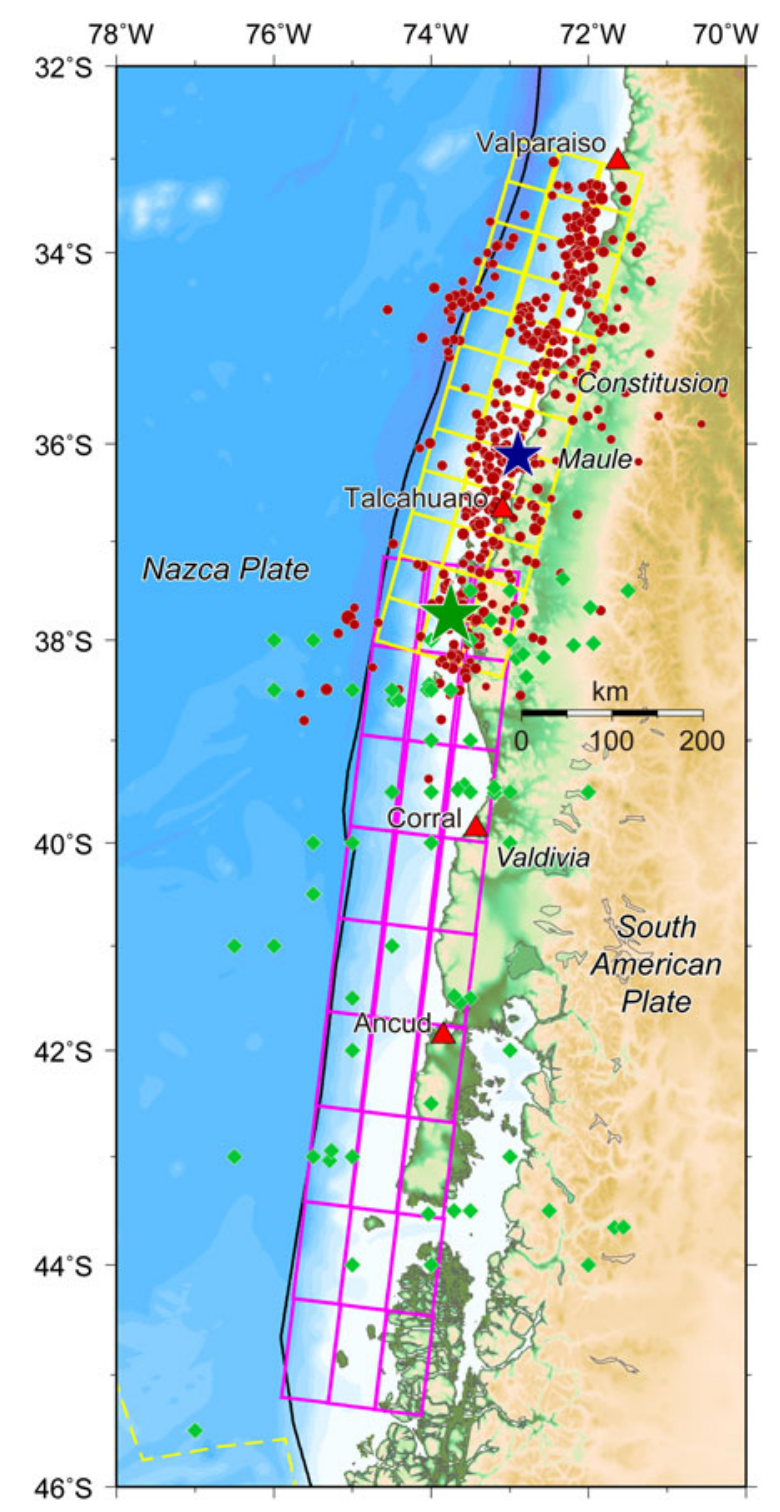

Figure 1

Epicenters of the 2010 Maule earthquake (blue star) and 1960 Valdivia earthquake (green star). Red circles and green diamonds indicate aftershocks within 1 day after each mainshock [location data from USGS and International Seismological Centre (ISC) for the 2010 and 1960 events, respectively]. Configurations of subfault models used in this study are shown by yellow and purple rectangles for the 2010 and 1960 earthquakes, respectively. Black line indicates plate boundary of Nazca and South America Plates.

Locations of tide gauges (red triangles) are also shown

they are earlier than the observed ones in the northwestern Pacific, while the waveforms are similar. The cause of this discrepancy is currently unknown, hence we decided to use only tsunami waveforms recorded in South America (for both the
1960 and 2010 tsunamis) and DART stations in the southeastern Pacific (for the 2010 tsunami).

\subsection{Near-Field Tsunamis}

Both the 2010 and 1960 earthquakes caused significant tsunami damage along the Chilean coast. For the 2010 tsunami, a total of 156 persons were killed and 25 people are missing, including many campers (UNESCO/IOC, 2010). Post-tsunami surveys reported runup heights up to $15 \mathrm{~m}$ along the Chilean coast, but with a localized maximum runup height of $29 \mathrm{~m}$ near Constitucion (FriTz et al., 2011). At the Talcahuano tide gauge station, after the small initial receding wave, the first tsunami wave was recorded with amplitude of $2.3 \mathrm{~m}$ and long period of $30 \mathrm{~min}$. The record stopped at $110 \mathrm{~min}$ as the rising limb of the second tsunami surge exceeded $2.9 \mathrm{~m}$ amplitude. At the Valparaiso tide gauge station, located in the northern part of the source region, the first wave with amplitude of $1.6 \mathrm{~m}$ was observed, and the maximum wave of $2.3 \mathrm{~m}$ was recorded about $2 \mathrm{~h}$ later. According to the post-tsunami survey (IMAMuRA et al., 2010), some eyewitnesses and private video reported that the maximum tsunami wave arrived after the first wave. The tide gauge records at Talcahuano and Valparaiso also show such late large tsunami phases.

The 1960 earthquake killed about 1,655 people and injured 3,000, and 2,000,000 were displaced in southern Chile. The tsunami heights along the Chilean coast were reported as 10-20 m (Hellmuth et al., 1963). The tsunami was also instrumentally recorded at coastal tide gauges. At Talcahuano, just to the north of the epicenter (Fig. 1), a maximum amplitude of $\sim 3 \mathrm{~m}$ was recorded. The tsunami was also recorded at other tide gauges in South America, while their amplitudes are mostly $<1 \mathrm{~m}$.

\section{Tsunami and Geodetic Data Used for Inversion}

\subsection{Tsunami Data}

For the 2010 tsunami, we used tsunami waveforms recorded at 11 tide gauge stations in Chile and Peru (Fig. 4). We processed these records to retrieve the tsunami signals as follows. We first approximate the tidal component as a polynomial function, and 


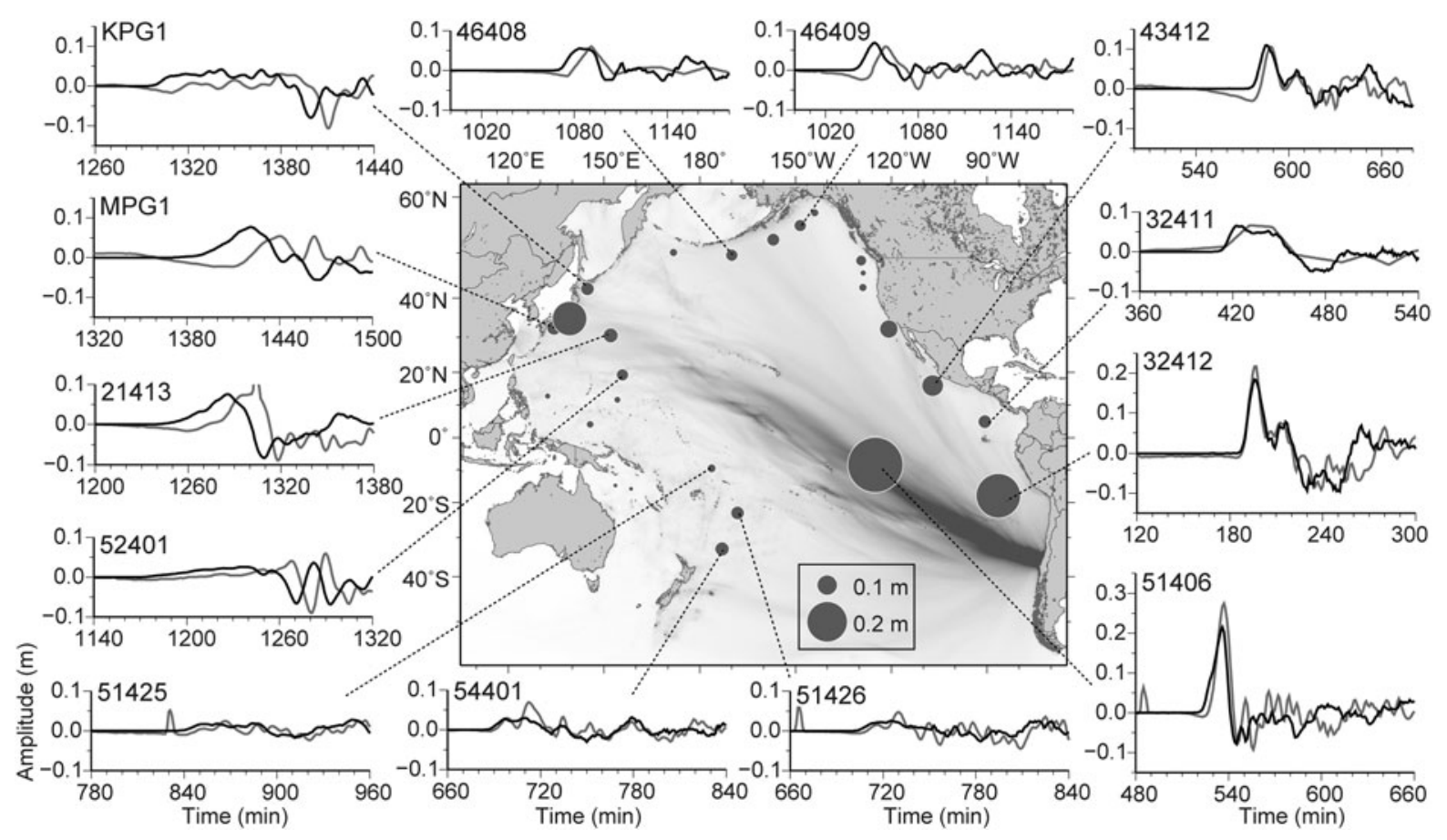

Figure 2

Gray scale in the Pacific Ocean shows distribution of tsunami amplitude computed from a uniform-slip fault model (fault length $400 \mathrm{~km}$, width $150 \mathrm{~km}$, slip $10 \mathrm{~m}$ ) of the 2010 Chilean earthquake, and solid circles show the tsunami amplitudes observed at OBPG stations. Comparison of tsunami waveforms at DART (five-digit numeral) and cable stations near the Pacific coasts of Japan are shown around the map. Gray lines show the observed tsunami waveforms. Black lines show the synthetic tsunami waveforms computed from the source model estimated by joint inversion. Time is measured from the earthquake origin time

remove it from the original records. The observed tsunami waveforms indicate that the tsunami amplitudes range from several tens of centimeters to a few meters at Chilean and Peruvian tide gauges (see Fig. 7 shown later). In addition, we used tsunami waveforms recorded at four DART stations (51406, 43412, 32411, and 32412) (Fig. 4). For the DART data, we retrieved the tsunami signals by first removing the tidal components. We then applied a moving average of three sampling points to reduce the high-frequency noise.

For the 1960 tsunami, we used the waveform data recorded at 12 tide gauge stations, mostly in South America (Fig. 4). Among them, six (Talcahuano, Valparaiso, Coquimbo, Caldera, Antofagasta, and Arica) were recorded on the Chilean coast. Note that all the stations were located to the north of the 1960 earthquake source. We first scanned the tsunami waveforms from Berkman and Symons (1964), digitized them, and removed the tidal components in a similar way as we did for the 2010 digital data.

\subsection{Coastal Uplift and Subsidence Data}

For the 2010 Maule earthquake, we used coastal uplift and subsidence data at 36 locations collected by FARIAS et al. (2010) (Fig. 5a). Large uplifts of $1.5-2.5 \mathrm{~m}$ and subsidence as large as $1 \mathrm{~m}$ were observed in the southern part of the source area. In the northern part of the source area, small uplift and subsidence of 0-0.5 m were observed. For the 1960 earthquake, we used coastal uplift and subsidence measured at 155 points and leveling data along a 580-km-long highway (Plafker and SAVAGE, 1970). We digitized the leveling data drawn by PlAFKER and SAVAGE (1970) with 146 points, although the original data points are much more sparse. Most of the coastal points and the highway subsided by amounts of 


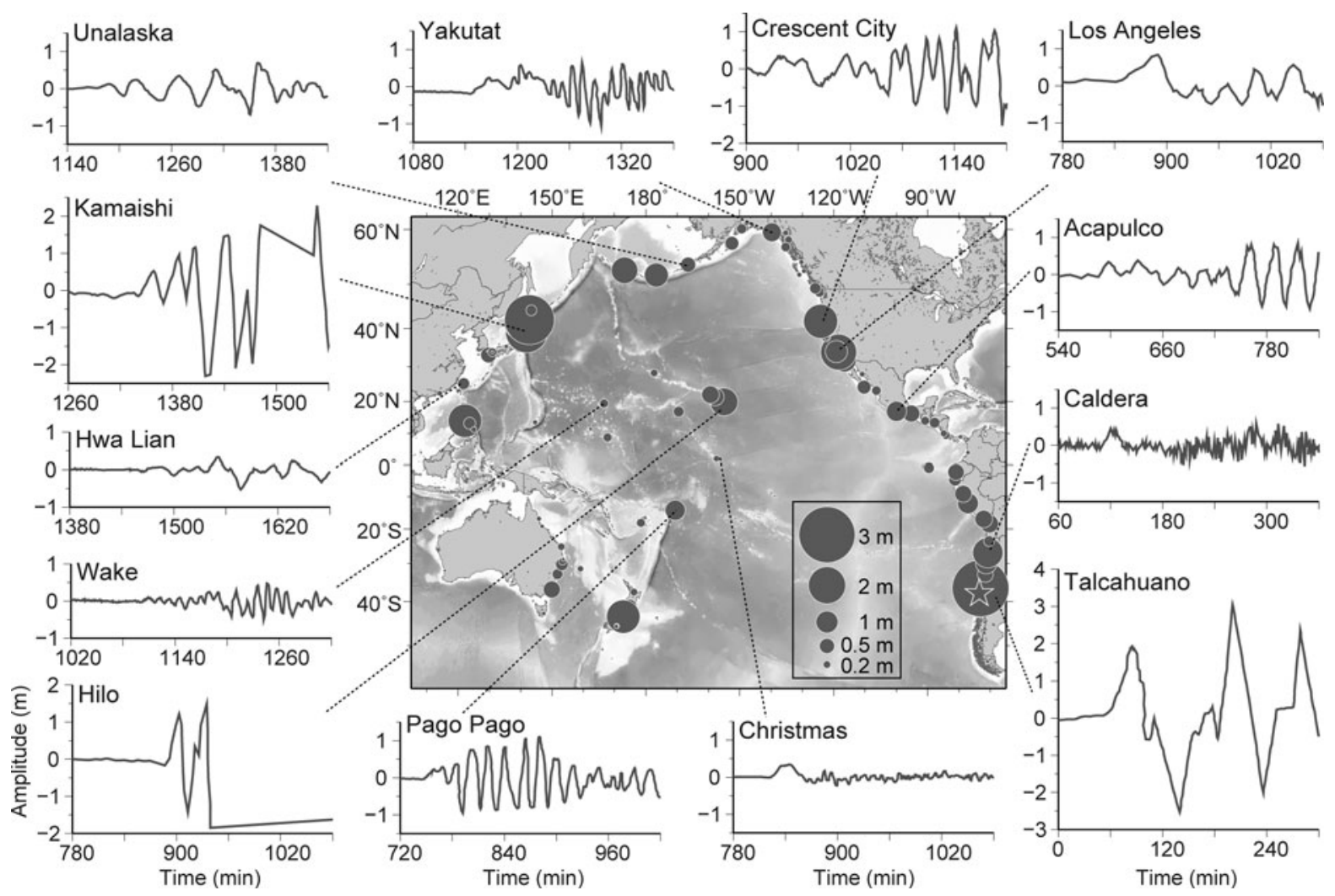

Figure 3

Maximum amplitudes of observed tsunami waveforms (circles) and representative tsunami waveforms from the 1960 Chilean earthquake. Time is measured from the earthquake origin time. Epicenter is shown by star

$0-2 \mathrm{~m}$ as shown in Fig. $5 \mathrm{~b}$. The uplifted points are limited to the offshore islands (Isla Mocha, Isla Guafo, and Isla Guamblin) and the inland part of Gulfo de Ancud (Bay of Ancud).

\section{Inversion}

\subsection{Subfaults and Crustal Deformation}

For the 2010 Maule earthquake, we assumed $12 \times 3$ subfaults $(50 \mathrm{~km} \times 50 \mathrm{~km})$ along the strike and downdip direction, respectively, to cover the aftershock distribution (Figs. 1, 5a). The updip depths of the subfaults are $0,12.1$, and $24.2 \mathrm{~km}$ for the shallow, middle, and deep subfaults, respectively. The strike of $16^{\circ}$, dip angle of $14^{\circ}$, and slip angle of $104^{\circ}$ are from the USGS's W phase moment tensor solution and are constant for each subfault. For the 1960 earthquake, we used the fault geometry from the uniform-slip model of BARRIENTOS and WARD (1990).
The focal mechanism parameters are strike of $7^{\circ}$ along the trench axis, dip angle of $20^{\circ}$, and slip angle of $105^{\circ}$. We divided the source area into $9 \times 3$ subfaults $(100 \mathrm{~km} \times 50 \mathrm{~km})$ along the strike and downdip direction, respectively (Figs. 1, 5b). The updip depths of the subfaults are $0,17.1$, and $34.2 \mathrm{~km}$ for the shallow, middle, and deep subfaults, respectively.

Static deformation of seafloor was calculated using the rectangular fault model (OKADA, 1985). This provides the initial condition for the tsunami numerical computation, assuming that the initial water height distribution is the same as that of the seafloor. We also consider the effects of coseismic horizontal displacement in regions of steep bathymetric slopes (TANiOKa and SATAKe, 1996).

\subsection{Tsunami Computations}

To calculate tsunami propagation from the source to tide gauge or offshore stations, the linear shallow- 


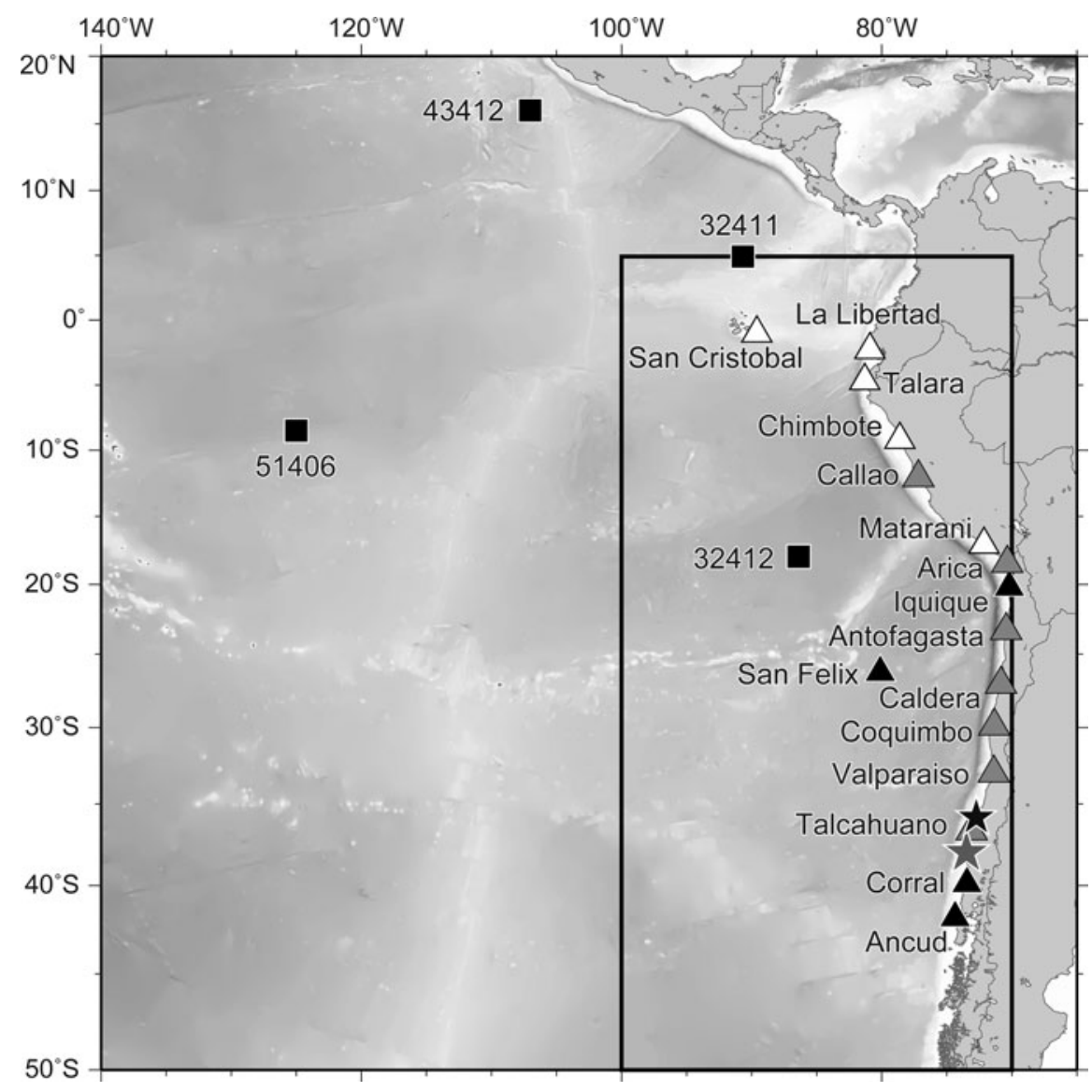

Figure 4

Locations of DART (squares) and tide gauges (triangles) which were used for inversions in this study. Stations filled in black, white, and gray were used for the 2010 or 1960 earthquakes and both of them, respectively. Epicenters are also shown by black and gray stars for the 2010 and 1960 events, respectively. Rectangle shows the computation area for the near-field tsunami

water, or long-wave, equations were numerically solved by using a finite-difference method (SATAKE, 1995). Details of the governing equations are described in FuJII and SATAKE (2007). Tsunami waveforms were calculated assuming a constant rise time (or slip duration) of 30 and $60 \mathrm{~s}$ for each subfault of the 2010 and 1960 subfault models, respectively, to reflect the size of subfaults. We assumed that slip occurs simultaneously on all the subfaults, or the rupture velocity is infinite, because the tsunami waveforms at regional distances are insensitive to rupture along strike direction, and the temporal resolution of tsunami waveforms is limited (1 min).

We used two different bathymetry grids for calculating tsunami waveforms. For the near-field tsunami, we prepared a bathymetry grid of 30 arcsecond from GEBCO_08 data (BRITISH OCEANOGRAPHic Data Centre, 1997) to compute the $9 \mathrm{~h}$ tsunami propagation from the source to the tide gauge stations located in South America (rectangular area in Fig. 4). For the far-field tsunami recorded at the DART stations, we used a bathymetry gird of 2 arc-minute (about $3.7 \mathrm{~km}$ ). The minimum water depths on the coasts were set to $2 \mathrm{~m}$ for both bathymetry grids. The computational time steps are 2 and $6 \mathrm{~s}$ in the nearfield and far-field grids, respectively, to satisfy the stability condition for the finite-difference method. At the open-ocean boundary, the radiation condition is adopted, while at the land boundary, total reflection is assumed. 


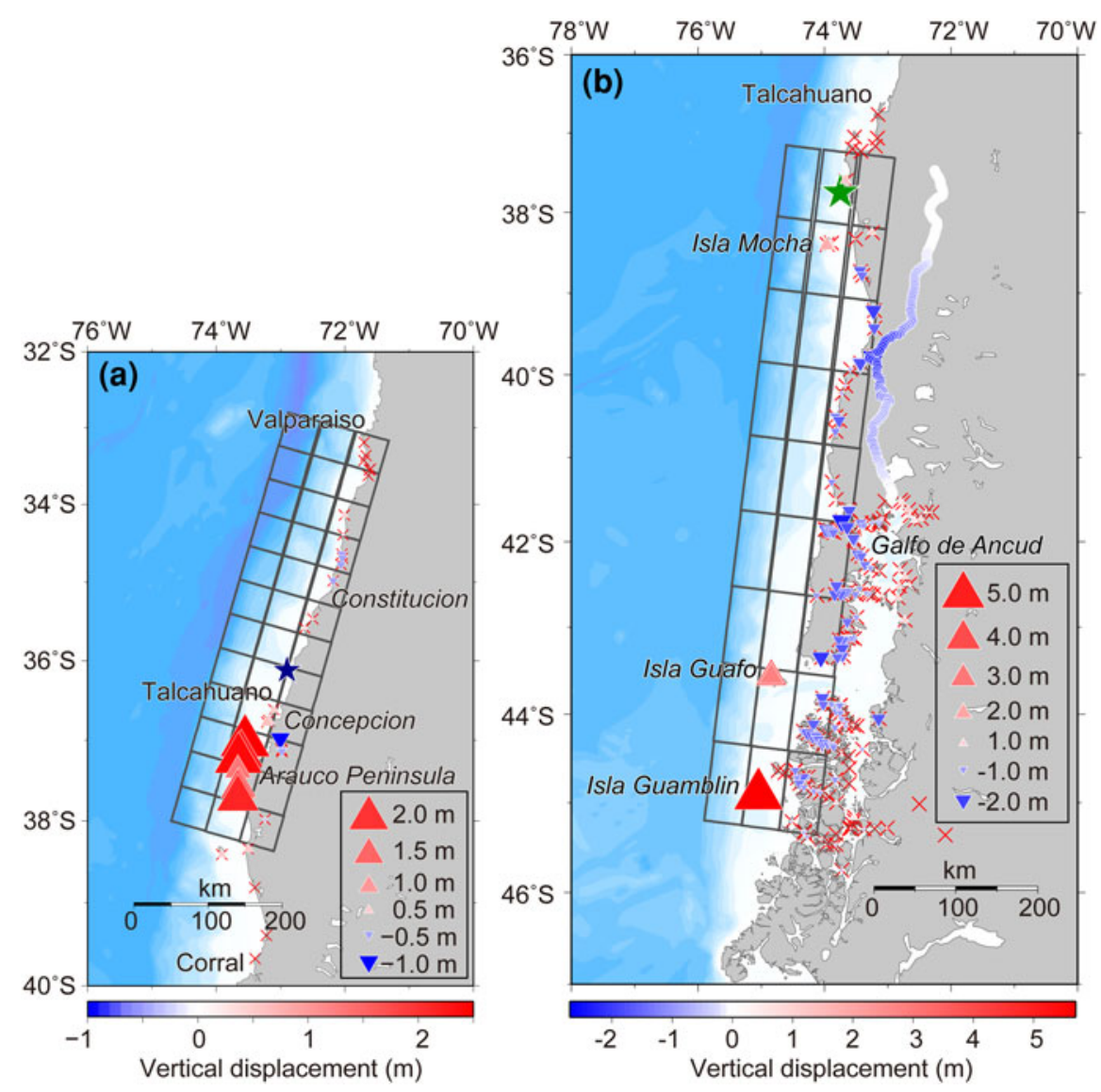

Figure 5

Land-level changes indicated by geodetic data from Farias et al. (2010) following the 2010 earthquake (a) and from PlafKer and SAVAGE (1970) following the 1960 earthquake (b) Locations of subfault models used in this study are shown by gray rectangles

\subsection{Inversion Method}

We used the non-negative least-squares method (LAWSON and HANSON, 1974) and delete-half jackknife method (TichelaAR and RUFF, 1989) to estimate the slip distribution and errors, respectively. The observed tsunami waveforms were resampled at a 1 min interval; hence the synthetic waveforms are also computed at $1 \mathrm{~min}$ interval. The total number of data points used for the tsunami waveform inversions is 1,065 for the 2010 earthquake, and 1,664 for the 1960 earthquake. Because the tsunami amplitudes at deep-ocean DART stations are about an order of magnitude smaller than those at coastal tide gauges, we weight the DART data by ten times. The total number of data points for the joint inversion is 1,101 for the 2010 earthquake, and 1,965 for the 1960 earthquake. For the joint inversion of the 1960 earthquake, we used the same method described in SATAKE (1993) to set weights for the tsunami and geodetic data. For the 1960 geodetic data, we weighted by a quarter (1/4) the 146 digitized points of leveling data along the highway, so that the average spatial intervals of coastal and leveling data are roughly the same.

\section{The 2010 Maule Earthquake}

\subsection{Results of Tsunami Waveform Inversion}

Inversion of tsunami waveforms alone shows two large slip regions; the first one is in the central part of the source area around Constitucion, and the second one is to the south near the Arauco Peninsula (Fig. 6a; Table 1). The large slip area near Constitucion is 

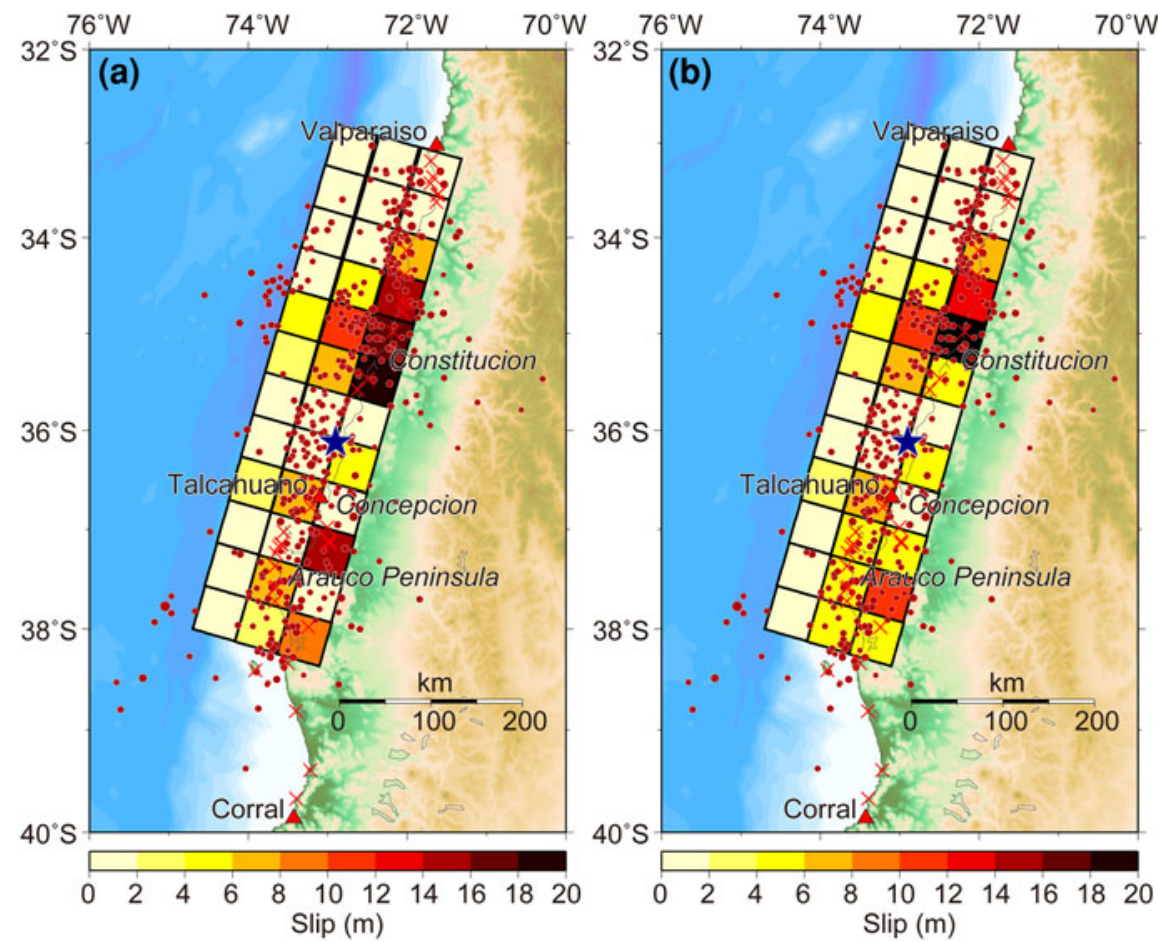

Figure 6

Slip distributions estimated by inversion using a tsunami data only and $\mathbf{b}$ joint data set including geodetic data. Blue star shows the 2010 epicenter. Circles indicate aftershocks within 1 day of the mainshock. Data points of geodetic data are also shown by crosses

located at the deepest subfaults beneath the coastline, with maximum slip of $19 \mathrm{~m}$. The largest slip around the Arauco Peninsula is also at the deepest subfault, with slip amount of $14 \mathrm{~m}$. The average slip on the 36 subfaults is $4.0 \mathrm{~m}$.

Such large slip on the deepest subfaults beneath the coastline were estimated by tsunami waveforms recorded at DART stations. We examined the tsunami waveforms, or tsunami Green's functions, at the coastal tide gauge and DART stations from each subfault, and found that the tsunami waveforms from offshore subfaults arrive at the DART stations earlier than observed. To match the tsunami arrival time at the DART stations, the source must be located beneath the coast or land. The synthetic tsunami waveforms from the estimated slip distribution generally agree with the observed ones at most stations (Fig. 7a). The initial small negative wave observed at Talcahuano is also reproduced.

The land-level changes calculated from this slip distribution suggest large costal uplift near Constitucion, whereas the field observation found subsidence
(Fig. 8a, b). Near the Arauco Peninsula, on the other hand, both calculations and observations show coastal uplift, but the calculated amount was smaller than the observed. These results indicate that the tsunami waveforms do not provide enough spatial resolution to accurately determine slip near the coast. We therefore made a joint inversion of tsunami and costal geodetic data.

\subsection{Results of Joint Inversion of Tsunami and Geodetic Data}

Slip distribution from the joint inversion also shows two large slip regions to the north and south of the epicenter (Fig. 6b; Table 1). The largest slip, $22 \mathrm{~m}$, is still located at the deepest subfault but shifted by $50 \mathrm{~km}$ to the north. The largest slip in the south around the Arauco Peninsula is also shifted towards the north. The average slip on the 36 subfaults is $3.75 \mathrm{~m}$.

The synthetic tsunami waveforms computed from the joint inversion are basically the same as those 
Table 1

Subfault location, depth, slip, and error for the 2010 earthquake. Slip distributions were estimated by tsunami waveforms and joint inversion including geodetic data

\begin{tabular}{|c|c|c|c|c|c|}
\hline \multirow[t]{2}{*}{ No. } & \multirow[t]{2}{*}{ Lat. $\left({ }^{\circ} \mathrm{S}\right)$} & \multirow[t]{2}{*}{ Lon. $\left({ }^{\circ} \mathrm{W}\right)$} & \multirow[t]{2}{*}{ Depth (km) } & \multicolumn{2}{|c|}{ Slip and error (m) } \\
\hline & & & & Tsunami & Tsunami + geodetic \\
\hline 1 & 38.00000 & 74.70000 & 0.0 & $0.00 \pm 0.00$ & $0.00 \pm 0.19$ \\
\hline 2 & 37.56674 & 74.54808 & 0.0 & $0.50 \pm 0.27$ & $0.00 \pm 0.60$ \\
\hline 3 & 37.13347 & 74.39615 & 0.0 & $0.00 \pm 0.00$ & $0.00 \pm 0.00$ \\
\hline 4 & 36.70021 & 74.24423 & 0.0 & $2.89 \pm 1.68$ & $2.24 \pm 1.00$ \\
\hline 5 & 36.26694 & 74.09230 & 0.0 & $0.00 \pm 0.42$ & $0.00 \pm 0.55$ \\
\hline 6 & 35.83368 & 73.94038 & 0.0 & $0.42 \pm 0.33$ & $1.32 \pm 0.59$ \\
\hline 7 & 35.40041 & 73.78845 & 0.0 & $2.56 \pm 1.03$ & $3.94 \pm 1.32$ \\
\hline 8 & 34.96715 & 73.63653 & 0.0 & $4.34 \pm 1.68$ & $4.69 \pm 1.59$ \\
\hline 9 & 34.53388 & 73.48460 & 0.0 & $1.64 \pm 0.98$ & $2.11 \pm 0.98$ \\
\hline 10 & 34.10062 & 73.33268 & 0.0 & $0.00 \pm 0.05$ & $0.00 \pm 0.14$ \\
\hline 11 & 33.66735 & 73.18075 & 0.0 & $0.00 \pm 0.17$ & $0.00 \pm 0.10$ \\
\hline 12 & 33.23409 & 73.02883 & 0.0 & $0.00 \pm 0.00$ & $0.00 \pm 0.00$ \\
\hline 13 & 38.12424 & 74.17018 & 12.1 & $3.53 \pm 2.81$ & $4.73 \pm 3.07$ \\
\hline 14 & 37.69097 & 74.01825 & 12.1 & $6.94 \pm 3.63$ & $4.21 \pm 3.07$ \\
\hline 15 & 37.25771 & 73.86633 & 12.1 & $0.00 \pm 0.20$ & $4.85 \pm 3.38$ \\
\hline 16 & 36.82444 & 73.71440 & 12.1 & $7.73 \pm 3.60$ & $7.33 \pm 2.92$ \\
\hline 17 & 36.39118 & 73.56248 & 12.1 & $0.34 \pm 0.27$ & $0.20 \pm 0.42$ \\
\hline 18 & 35.95791 & 73.41055 & 12.1 & $0.45 \pm 0.72$ & $1.92 \pm 1.00$ \\
\hline 19 & 35.52465 & 73.25863 & 12.1 & $6.86 \pm 3.84$ & $7.38 \pm 3.44$ \\
\hline 20 & 35.09138 & 73.10670 & 12.1 & $10.59 \pm 3.93$ & $10.06 \pm 3.99$ \\
\hline 21 & 34.65812 & 72.95478 & 12.1 & $4.31 \pm 1.89$ & $5.23 \pm 2.27$ \\
\hline 22 & 34.22485 & 72.80285 & 12.1 & $0.00 \pm 0.20$ & $0.14 \pm 0.13$ \\
\hline 23 & 33.79159 & 72.65093 & 12.1 & $0.37 \pm 2.04$ & $0.20 \pm 0.13$ \\
\hline 24 & 33.35832 & 72.49901 & 12.1 & $0.17 \pm 3.83$ & $0.00 \pm 0.16$ \\
\hline 25 & 38.24847 & 73.64035 & 24.2 & $8.54 \pm 4.23$ & $4.65 \pm 3.01$ \\
\hline 26 & 37.81521 & 73.48843 & 24.2 & $1.43 \pm 0.67$ & $11.18 \pm 5.45$ \\
\hline 27 & 37.38194 & 73.33650 & 24.2 & $14.37 \pm 6.95$ & $5.79 \pm 3.10$ \\
\hline 28 & 36.94868 & 73.18458 & 24.2 & $1.31 \pm 2.10$ & $1.36 \pm 1.13$ \\
\hline 29 & 36.51541 & 73.03265 & 24.2 & $5.68 \pm 2.26$ & $4.38 \pm 1.71$ \\
\hline 30 & 36.08215 & 72.88073 & 24.2 & $0.00 \pm 0.03$ & $0.00 \pm 0.77$ \\
\hline 31 & 35.64888 & 72.72880 & 24.2 & $18.79 \pm 10.57$ & $5.41 \pm 4.82$ \\
\hline 32 & 35.21562 & 72.57688 & 24.2 & $16.21 \pm 7.91$ & $22.22 \pm 9.26$ \\
\hline 33 & 34.78236 & 72.42495 & 24.2 & $15.82 \pm 13.49$ & $13.38 \pm 9.72$ \\
\hline 34 & 34.34909 & 72.27303 & 24.2 & $6.96 \pm 4.01$ & $6.08 \pm 2.60$ \\
\hline 35 & 33.91583 & 72.12111 & 24.2 & $0.00 \pm 0.00$ & $0.00 \pm 0.00$ \\
\hline 36 & 33.48256 & 71.96918 & 24.2 & $0.00 \pm 0.00$ & $0.00 \pm 0.00$ \\
\hline
\end{tabular}

Location [latitude (Lat.) and longitude (Lon.)] indicates the southwest corner of each subfault

from the tsunami inversion, and generally agree with the observed ones at most stations (Fig. 7b). The coastal movement around Constitucion calculated from the joint inversion become small and closer to the observed, although it shows slight uplift at the points where small subsidence was actually observed (Fig. 8a, c). Near the Arauco Peninsula, the calculated uplift from the joint inversion result is larger and closer to the observed amount than that from the tsunami inversion result. These indicate that the tsunami waveforms have less sensitivity for the slip distribution in the north-south, or along-strike, direction than the down-dip direction, while the costal geodetic data are more sensitive to the slip distribution on the coast.

\subsection{Source Size and Seismic Moment}

The source models from the tsunami and joint inversions yield total seismic moments of $1.8 \times$ $10^{22} \mathrm{Nm}(\mathrm{Mw} 8.8)$ and $1.7 \times 10^{22} \mathrm{Nm}(\mathrm{Mw} \mathrm{8.8})$, respectively, assuming rigidity of $5.0 \times 10^{10} \mathrm{~N} / \mathrm{m}^{2}$ 


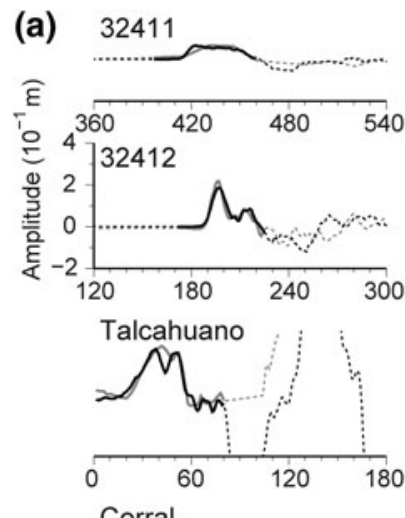

Corral

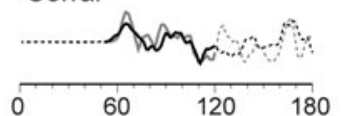

San Felix

......-1mph a
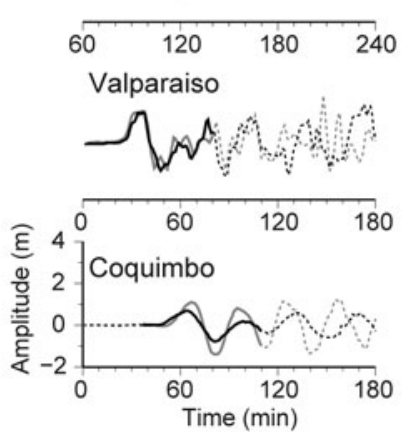

43412

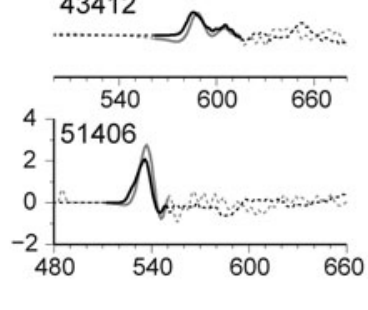

Caldera

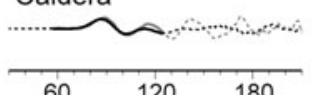

Antofagasta

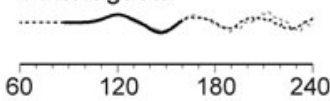

Iquique

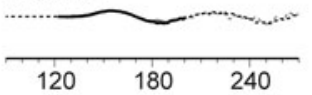

Arica
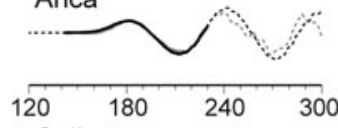

Callao

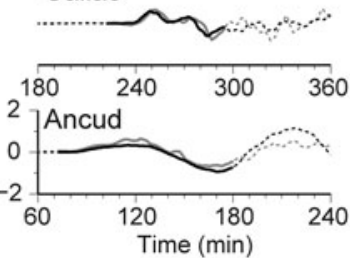

(b)

32411

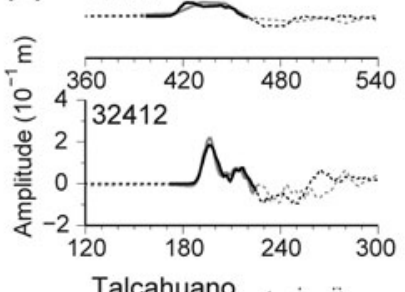

Talcahuano
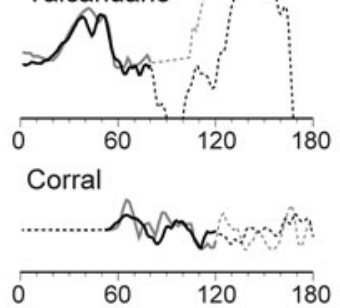

San Felix
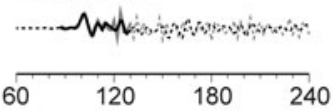

Valparaiso
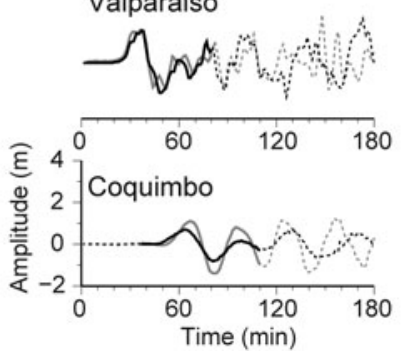

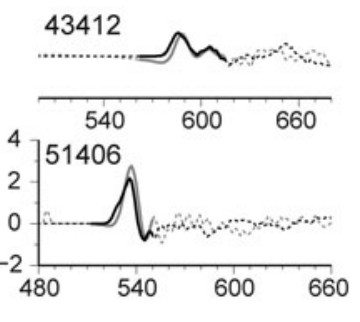

\section{Caldera}

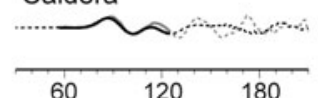

Antofagasta

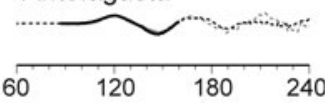

Iquique
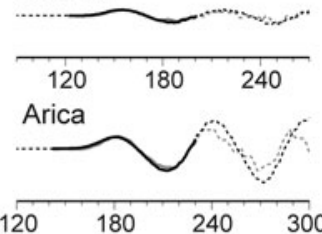

Callao

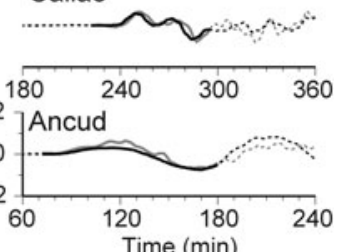

Figure 7

Comparison of tsunami waveforms for a tsunami data only and b joint inversion. Gray and black lines show the observed and synthetic tsunami waveforms computed from the slip distribution estimated with the 36-subfault model. Time ranges shown by solid curves are used for the inversions; the dashed parts are not used for the inversions, but shown for comparison. Time is measured from the earthquake origin time. Note the different vertical scale for DART and coastal tide gauge stations. The DART data are weighted ten times in the inversion so that the amplitudes in this plot are treated equally

for all subfaults. They both show that slip on the northern two subfaults are practically zero, hence the total fault length is about $500 \mathrm{~km}$. The two large slip regions, one to the north of the epicenter near the coast of Constitucion and the other to the south near the Arauco Peninsula, are considered as asperities in other studies (LAY et al., 2010; Delouis et al., 2010; TONG et al., 2010; LoRito et al., 2011; VIGNY et al., 2011). However, the models from seismic data (LAY et al., 2010) and GPS data (VIGNY et al., 2011) show that the two asperities are located offshore, whereas our result shows that both asperities are located at the deeper end of the fault beneath the coast. As mentioned before, the offshore asperity location produces computed tsunami arrival times at DART stations earlier than observed. The model by LORITO et al. (2011), based on tsunami and geodetic data, is very similar to ours.

\subsection{Tsunami Characteristics}

The later arrival of tsunami peaks reported from eyewitnesses or private videos are reproduced at the tide gauges of Talcahuano and Valparaiso (Fig. 7). Our modeling suggests that the late-arriving tsunami peaks were produced by tsunami propagation on a shallow continental shelf, or edge waves, and not from the large slip patches. We examined the 

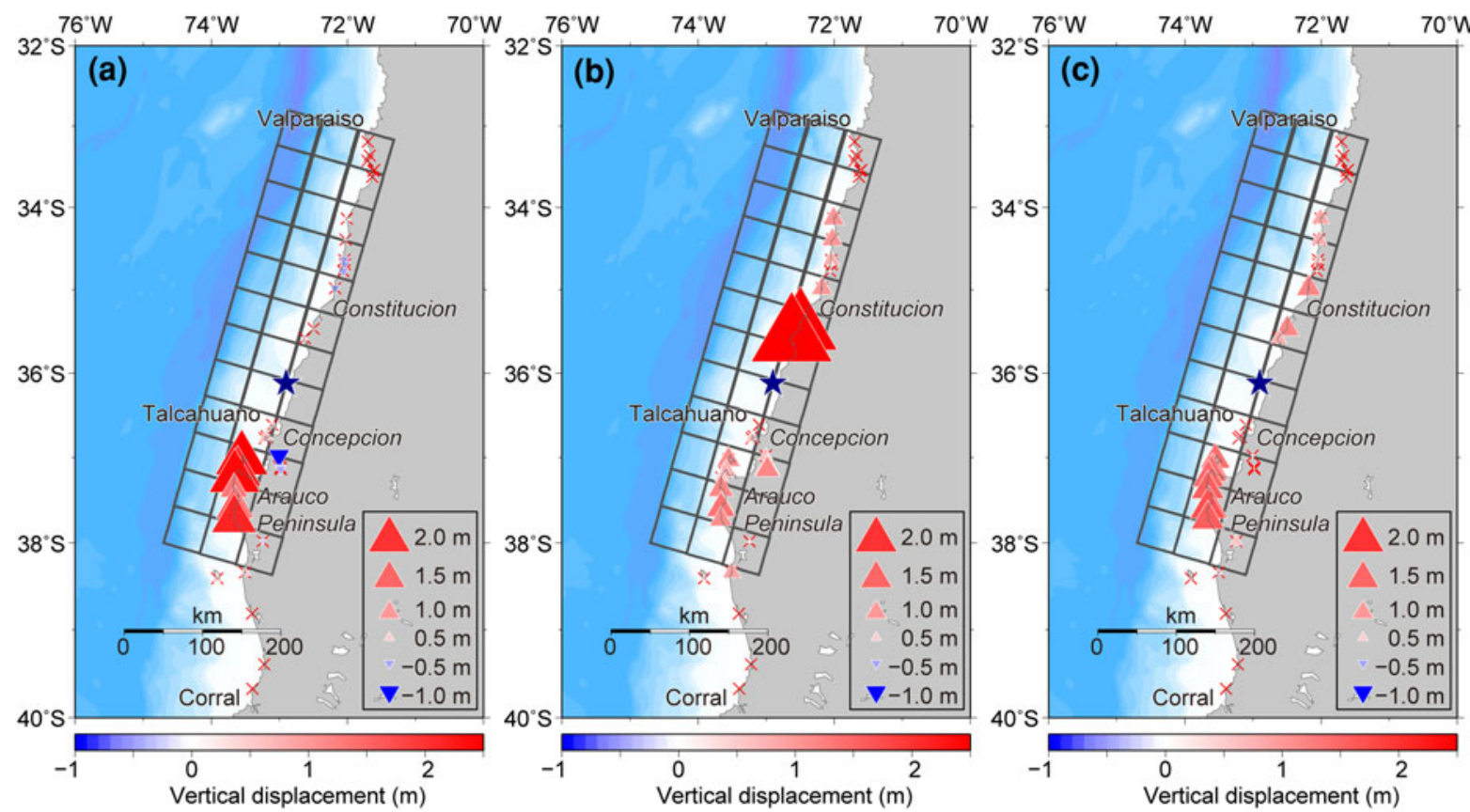

Figure 8

Comparison of a geodetic data observed by FARIAS et al. (2010) and calculated land-level changes by using the b tsunami waveform data only and $\mathbf{c}$ joint inversion results. Triangles and inverted triangles show uplift and subsidence, respectively
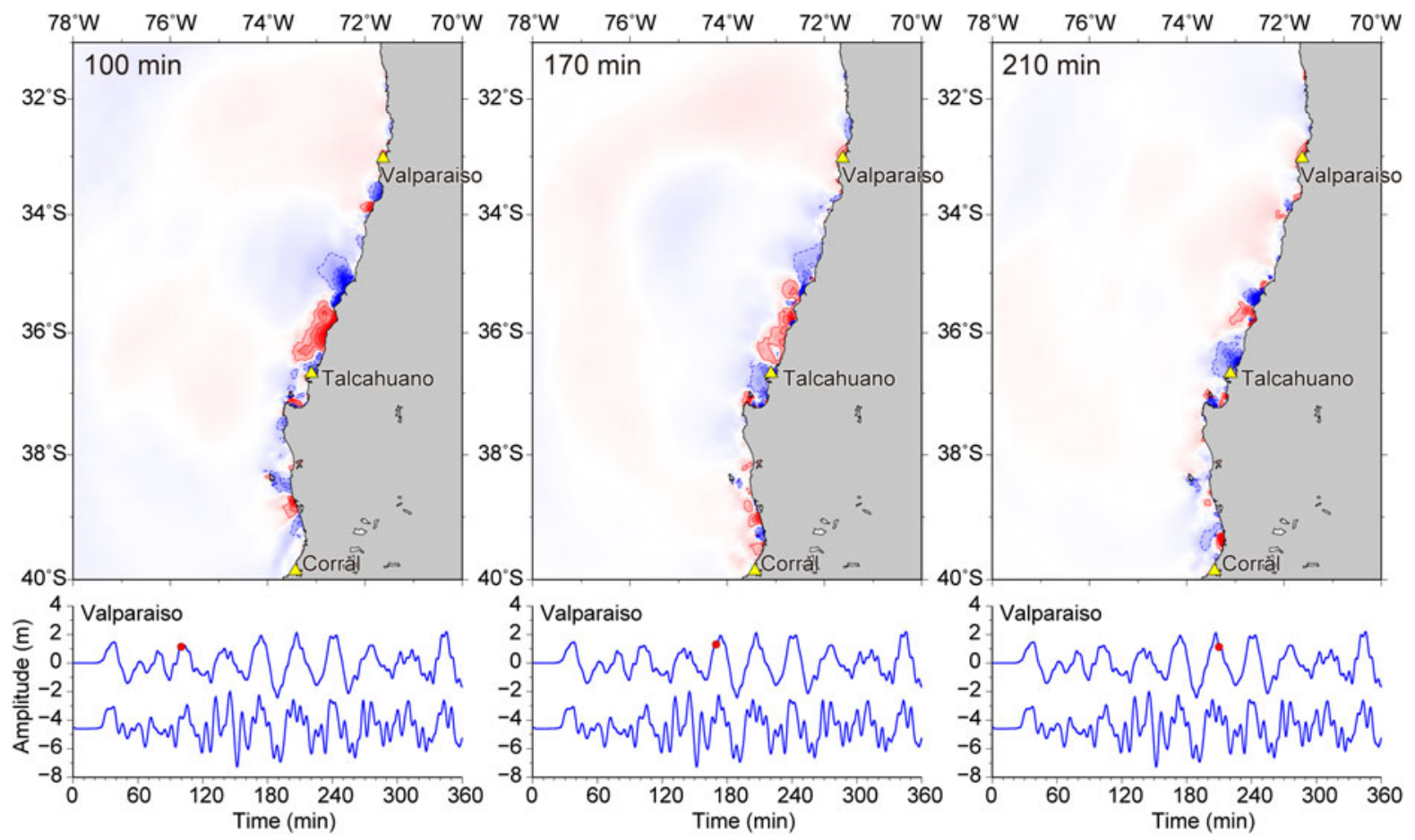

Figure 9

Sea-level distributions computed by a tsunami simulation using the joint inversion result for the 2010 Maule earthquake at 100 , 170 , and $210 \mathrm{~min}$ after the generation. Solid lines in red and dotted lines in blue indicate values above and below mean sea level, respectively, with contour interval of $0.5 \mathrm{~m}$. The synthetic tsunami waveforms at Valparaiso shown below each snapshot (red points show the snapshot time) are calculated by adopting the slip model from the joint inversion (upper curve) and a uniform-slip model (lower curve) 
waveforms and snapshots of tsunami propagation from the variable slip model obtained by the joint inversion and also from a uniform-slip model (Fig. 9), and found that the later peaks were reproduced in both cases. If the cause of the later phases is the large slip, the uniform model should not produce a large amplitude in tsunami later phase.

\section{1960 Valdivia Earthquake}

\subsection{Results of Tsunami Waveform Inversion}

The slip distribution from the inversion of tsunami waveforms shows very large slip at the deepest subfaults beneath the coast (Fig. 10a; Table 2). The largest slip amount is $90 \mathrm{~m}$, but the associated error is also large $(42 \mathrm{~m})$, indicating the estimated amount is not very reliable. The average slip on the 27 subfaults is $11 \mathrm{~m}$. One of the reasons for this unstable solution may be due to the station distribution. Unlike the 2010 Maule earthquake, all the stations where the tsunami waveforms were recorded are located north of the source region. While the computed tsunami waveforms generally reproduced the observations well (Fig. 11a), they may not be sensitive to slight shift of the slip distribution as we found for the case of the 2010 Maule earthquake. The large slip associated with the 1960 earthquake produces very large coastal uplift in the central part of the source area (Fig. 12b), where subsidence was actually observed (Fig. 12a) (PLAFKER and Savage, 1970). In the southern part, computed coastal uplift and subsidence are much larger than observed (Fig. 12a, b). These results also indicate that the inversion of tsunami waveforms recorded at the northern stations have less control on the slip distribution. We therefore made a joint inversion of tsunami and geodetic data, including coastal uplift and subsidence.
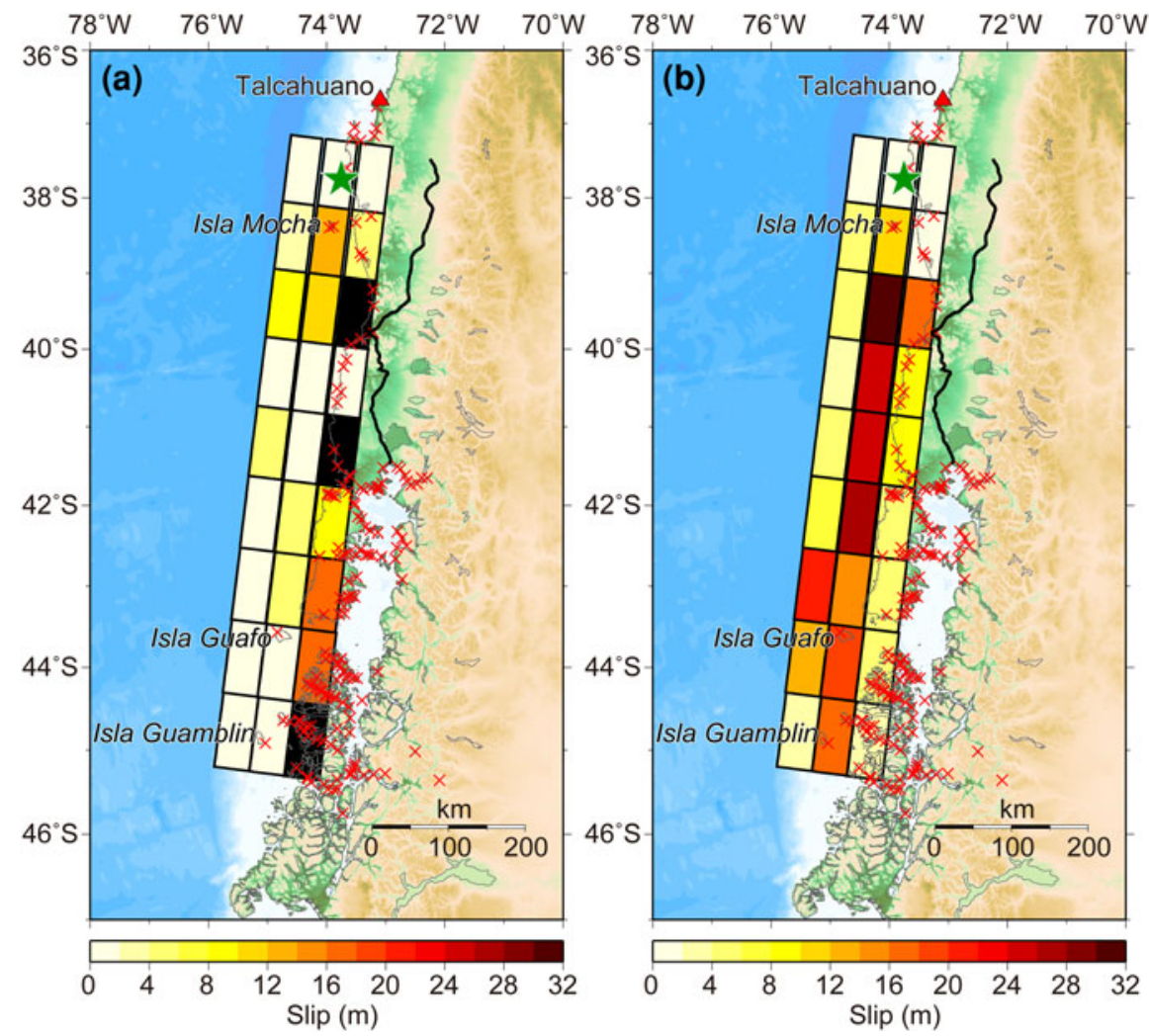

Figure 10

Slip distributions estimated by inversions using a tsunami data only and b joint data set including geodetic data. Green star shows the 1960 epicenter. Data points of geodetic data are also shown by crosses. Solid line in black shows the track of leveling data along the highway 


\subsection{Results of Joint Inversion}

The slip distribution from the joint inversion is quite different from that determined from tsunami waveforms alone (Fig. 10b; Table 2). Large slip of $25-30 \mathrm{~m}$ is estimated $200-500 \mathrm{~km}$ south of the epicenter on offshore subfaults. Such offshore slip produces coastal subsidence, as observed by PLAFKER and Savage (1970). In the southern part of the source, large offshore slip of $13-21 \mathrm{~m}$ is estimated near the trench. On small offshore islands, Isla Guafo and Isla Guamblin, large uplifts (3.6 and $5.7 \mathrm{~m}$ ) were reported. The average slip on the 27 subfaults is $11 \mathrm{~m}$.

The tsunami waveforms computed from the joint inversion result are similar to those from the tsunami inversion, and generally agree with the observed ones at most stations (Fig. 11b). At a few stations
(Antofagasta and Arica), the synthetic waveforms from the joint inversion match the observed waveforms better than the synthetic waveforms from the tsunami inversion. The computed coastal movements, both uplift and subsidence, from the joint inversion results reproduce the observed movements well (Fig. 12c) along the entire coastline.

\subsection{Source Size and Slip Distribution}

The total seismic moments from the tsunami and joint inversion results are 7.3 and $7.2 \times 10^{22} \mathrm{Nm}$ $(\mathrm{Mw}=9.2)$, respectively, assuming rigidity of $5.0 \times 10^{10} \mathrm{~N} / \mathrm{m}^{2}$ for all subfaults. The fault length is about $800 \mathrm{~km}$, if we ignore the northernmost subfaults with small slip. The seismic moment from the tsunami or joint inversion is similar to those

Table 2

Subfault location, depth, slip, and error for the 1960 earthquake

\begin{tabular}{|c|c|c|c|c|c|}
\hline \multirow[t]{2}{*}{ No. } & \multirow[t]{2}{*}{ Lat. $\left({ }^{\circ} \mathrm{S}\right)$} & \multirow[t]{2}{*}{ Lon. $\left({ }^{\circ} \mathrm{W}\right)$} & \multirow[t]{2}{*}{ Depth $(\mathrm{km})$} & \multicolumn{2}{|c|}{ Slip and error (m) } \\
\hline & & & & Tsunami & Tsunami + geodetic \\
\hline 1 & 45.20000 & 75.90000 & 0.0 & $1.71 \pm 0.92$ & $3.05 \pm 1.50$ \\
\hline 2 & 44.30611 & 75.75513 & 0.0 & $0.00 \pm 0.02$ & $12.76 \pm 5.56$ \\
\hline 3 & 43.41222 & 75.61026 & 0.0 & $1.44 \pm 0.96$ & $21.42 \pm 8.89$ \\
\hline 4 & 42.51832 & 75.46538 & 0.0 & $1.68 \pm 2.96$ & $6.48 \pm 2.43$ \\
\hline 5 & 41.62443 & 75.32051 & 0.0 & $4.62 \pm 2.01$ & $4.11 \pm 1.74$ \\
\hline 6 & 40.73054 & 75.17564 & 0.0 & $0.00 \pm 0.95$ & $2.34 \pm 1.14$ \\
\hline 7 & 39.83665 & 75.03077 & 0.0 & $9.25 \pm 3.73$ & $5.54 \pm 2.80$ \\
\hline 8 & 38.94276 & 74.88590 & 0.0 & $3.88 \pm 1.53$ & $4.16 \pm 1.94$ \\
\hline 9 & 38.04887 & 74.74102 & 0.0 & $0.30 \pm 0.20$ & $0.76 \pm 0.46$ \\
\hline 10 & 45.25488 & 75.31006 & 17.1 & $0.00 \pm 2.21$ & $17.09 \pm 7.90$ \\
\hline 11 & 44.36099 & 75.16518 & 17.1 & $0.00 \pm 1.44$ & $18.12 \pm 9.30$ \\
\hline 12 & 43.46709 & 75.02031 & 17.1 & $5.75 \pm 5.62$ & $14.81 \pm 7.47$ \\
\hline 13 & 42.57320 & 74.87544 & 17.1 & $5.46 \pm 2.96$ & $27.38 \pm 12.43$ \\
\hline 14 & 41.67931 & 74.73057 & 17.1 & $0.00 \pm 0.00$ & $24.69 \pm 10.20$ \\
\hline 15 & 40.78542 & 74.58569 & 17.1 & $1.98 \pm 4.58$ & $25.93 \pm 10.55$ \\
\hline 16 & 39.89153 & 74.44082 & 17.1 & $10.21 \pm 4.93$ & $30.07 \pm 10.76$ \\
\hline 17 & 38.99764 & 74.29595 & 17.1 & $12.10 \pm 5.17$ & $10.76 \pm 4.10$ \\
\hline 18 & 38.10374 & 74.15108 & 17.1 & $0.43 \pm 0.20$ & $1.14 \pm 0.64$ \\
\hline 19 & 45.30976 & 74.72011 & 17.1 & $90.01 \pm 42.70$ & $2.26 \pm 1.12$ \\
\hline 20 & 44.41586 & 74.57524 & 17.1 & $17.36 \pm 9.82$ & $4.55 \pm 2.61$ \\
\hline 21 & 43.52197 & 74.43037 & 17.1 & $17.48 \pm 11.23$ & $5.14 \pm 2.26$ \\
\hline 22 & 42.62808 & 74.28549 & 34.2 & $8.87 \pm 6.27$ & $5.51 \pm 3.98$ \\
\hline 23 & 41.73419 & 74.14062 & 34.2 & $40.08 \pm 17.84$ & $9.59 \pm 5.31$ \\
\hline 24 & 40.84030 & 73.99575 & 34.2 & $0.00 \pm 2.09$ & $9.41 \pm 4.44$ \\
\hline 25 & 39.94641 & 73.85088 & 34.2 & $53.22 \pm 23.42$ & $17.53 \pm 12.17$ \\
\hline 26 & 39.05251 & 73.70601 & 34.2 & $4.14 \pm 5.97$ & $1.00 \pm 0.59$ \\
\hline 27 & 38.15862 & 73.56113 & 34.2 & $0.00 \pm 0.16$ & $1.83 \pm 0.83$ \\
\hline
\end{tabular}

Slip distributions were estimated by tsunami waveforms and joint inversion including geodetic data

Location [latitude (Lat.) and longitude (Lon.)] indicates the southwest corner of each subfault 
(a)
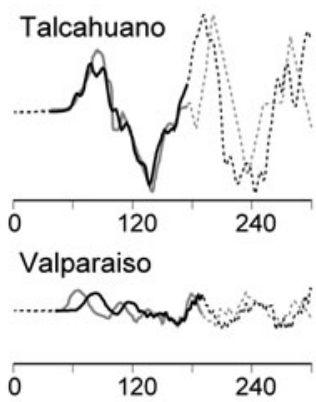

Coquimbo

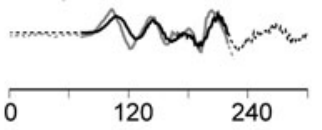

Caldera
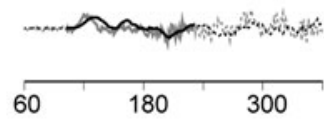

Antofagasta
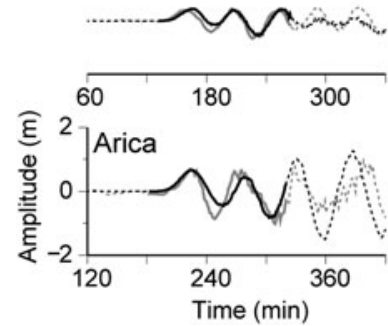

Matarani
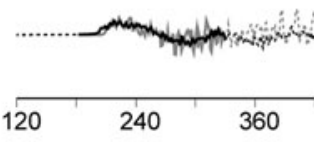

La Punta
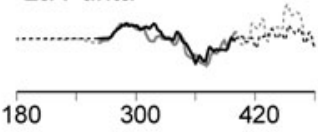

Chimbote

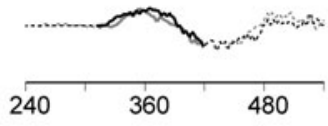

Talara
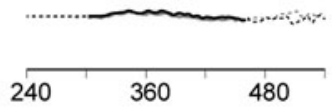

La Libertad
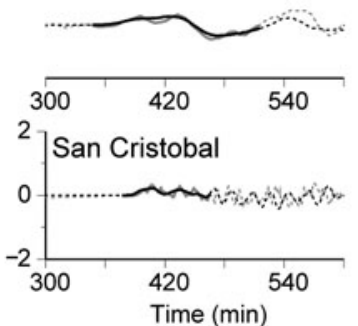

(b)
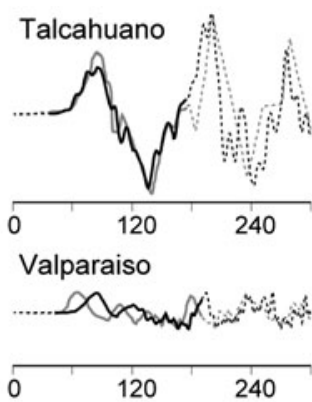

Coquimbo

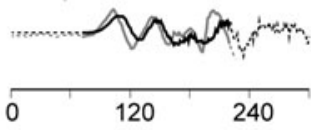

Caldera
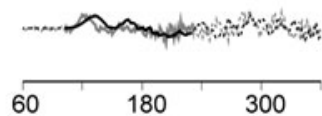

Antofagasta
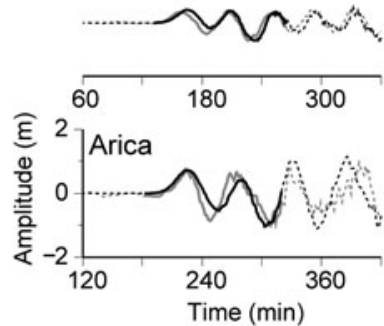

Matarani
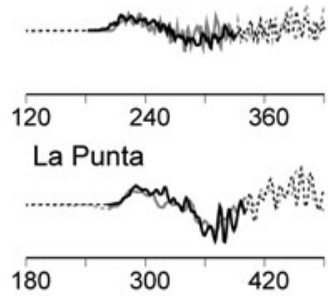

Chimbote

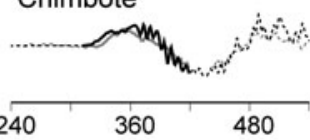

Talara
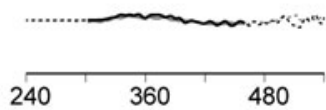

La Libertad
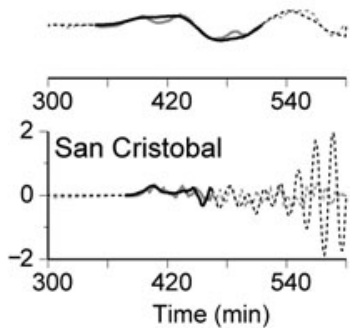

Figure 11

Comparison of tsunami waveforms for $\mathbf{a}$ tsunami data only and $\mathbf{b}$ joint inversion including geodetic data. Gray and black lines show the observed and synthetic tsunami waveforms computed from the slip distributions estimated with the 27 -subfault model. Time ranges shown by solid curves are used for the inversions; the dashed parts are not used for the inversions, but shown for comparison. Time is measured from the earthquake origin time

estimated by other studies from geodetic data. BARRIENTOS and WARD (1990) used the same geodetic data and estimated a seismic moment of 9.4 and $9.5 \times 10^{22} \mathrm{Nm}$ for the uniform and variable slip models, respectively. MoReno et al. (2009) estimated a seismic moment of 9.6 and $9.7 \times 10^{22} \mathrm{Nm}$ for curved and planar faults, respectively. These geodetic models indicate a moment magnitude $\mathrm{Mw}$ for the 1960 earthquake of 9.2-9.3.

The seismic moment estimated from seismic data are much larger. KANAMORI and CIPAR (1974) used teleseismic body waves to obtain $3 \times 10^{23} \mathrm{Nm}$ for the mainshock, and $6 \times 10^{23} \mathrm{Nm}$ if the precursory slow slip is included. KANAMORI and ANDERSON (1975) used free oscillation data to estimate a seismic moment of $2 \times 10^{23}$ and $4-5 \times 10^{23} \mathrm{Nm}$ without and with the precursory slip, respectively. CIFUENTES and SiLVER (1989) also used normal mode data to obtain 3.2 and $5.5 \times 10^{23} \mathrm{Nm}$, respectively. The moment magnitude $\mathrm{Mw}$ from seismic data thus ranges from 9.5 to 9.8 .

The large discrepancy between the seismically estimated moment and geodetic moment was speculated as being caused by offshore slip (BARRIENTOS and WARD, 1990), because the costal geodetic data are insensitive to the offshore slip. However, our results of tsunami inversion and joint inversion show that the 1960 seismic moment was similar to the geodetic moment. Hence it is unlikely that large seismic moment was hidden offshore. To confirm this, we added large $(10 \mathrm{~m})$ slip at offshore subfaults and computed tsunami waveforms. They are richer in 

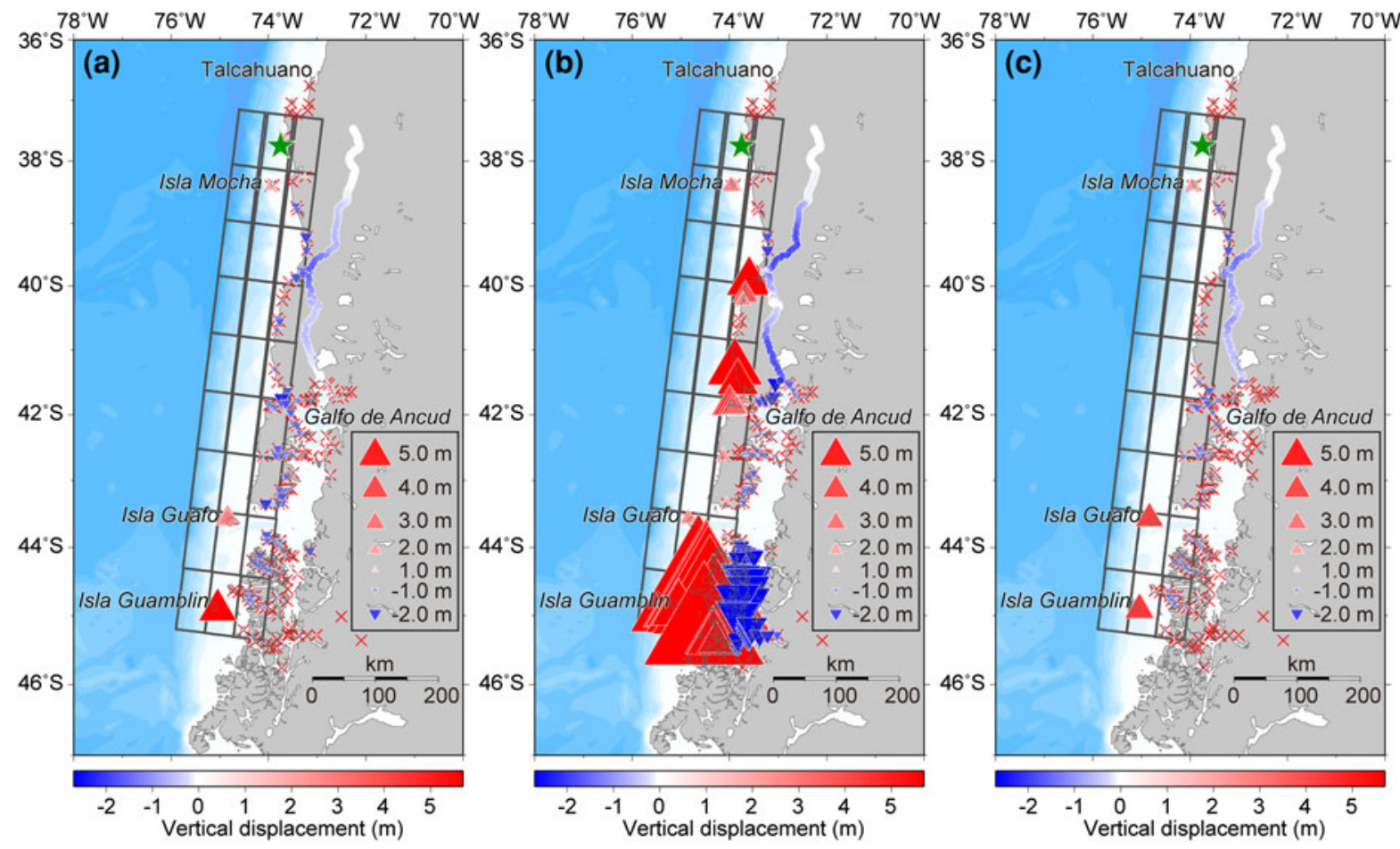

Figure 12

Comparison of a geodetic and leveling data from PlafKer and SAvage (1970) and calculated land-level changes by using the b tsunami waveform data only and $\mathbf{c}$ joint inversion including geodetic data. Triangles and inverted triangles show uplift and subsidence, respectively

short-period component and different from the observed waveforms. The larger seismic moment from seismic wave analysis might have included slips on deeper extension of the fault, not covered by the leveling data, if the seismic analyses did not overestimate the moment.

\section{Conclusions}

We inverted tsunami waveform and geodetic data to estimate the slip distribution of the 2010 and 1960 Chilean earthquakes. For the 2010 Maule earthquake, large slip beneath the coast (deeper subfaults) was estimated from tsunami waveforms. Joint inversion of tsunami and coastal geodetic data yields a seismic moment of $1.7 \times 10^{22} \mathrm{Nm}$ (Mw 8.8), with large slip located around Constitucion. The fault length is approximately $500 \mathrm{~km}$. Simulation of both uniform and heterogeneous slip models reproduced a delayed maximum wave, indicating that an edge wave was the cause. For the 1960 Valdivia earthquake, joint inversion yields a seismic moment of $7.2 \times 10^{22} \mathrm{Nm}$ (Mw 9.2) and a fault length of about $800 \mathrm{~km}$. Both the seismic moment and slip distribution are similar to those from geodetic data. The seismic moment is much smaller than the seismic estimates.

\section{Acknowledgments}

The 2010 tsunami waveforms at coastal tide gauges were collected by West Coast/Alaska Tsunami Warning Center (WCATWC). The data of oceanbottom pressure gauges of the Japan Agency for Marine-Earth Science and Technology (JAMSTEC) and DART stations by NOAA were downloaded from their websites. We also thank Dr. Sergio Barrientos for providing us copies of leveling data from the 1960 earthquake. Most of the figures were generated using the Generic Mapping Tools (Wessel and SMITH, 1998). We also thank two anonymous reviewers and guest editor Dr. Jose Borrero, whose comments on the manuscript improved the paper. This research was 
partially supported by Grants-in-Aid for Scientific Research (B) (No. 21310113), Ministry of Education, Culture, Sports, Science, and Technology (MEXT).

Open Access This article is distributed under the terms of the Creative Commons Attribution License which permits any use, distribution, and reproduction in any medium, provided the original author(s) and the source are credited.

\section{REFERENCES}

ABE, K. (1979), Size of great earthquakes of 1837-1974 inferred from tsunami data, J. Geophys. Res., 84(NB4), 1561-1568.

Altamimi, Z., Collilieux, X., Legrand, J., Garayt, B., and BouCHER, C. (2007), ITRF2005: A new release of the International Terrestrial Reference Frame based on time series of station positions and earth orientation parameters, J. Geophys. Res., 112(B9).

BARrientos, S. E., and WARD, S. N. (1990), The 1960 Chile earthquake-inversion for slip distribution from surface deformation, Geophysical Journal International, 103(3), 589-598.

Ben-Menahem, A. (1971), Force system of Chilean earthquake of 1960 May 22, Geophys. J. Royal Astronomical Soc., 25(4), 407-417.

Berkman, S. C., and Symons, J. M. (1964), The Tsunami of May 22, 1960 as Recorded at Tide Stations, U.S. Department of Commerce, Coast and Geodetic Survey, pp.79.

British Oceanographic Data Centre (1997), The Centenary Edition of the GEBCO Digital Atlas (CD-ROM).

Cifuentes, I. L., and Silver, P. G. (1989), Low-frequency source characteristics of the great 1960 Chilean earthquake, J. Geophys. Res., 94(B1), 643-663.

Cisternas, M., Atwater, B. F., Torrejon, F., Sawai, Y., Machuca, G., Lagos, M., Eipert, A., Youlton, C., Salgado, I., Kamataki, T., Shishikura, M., Rajendran, C. P., Malik, J. K., Rizal, Y., and Husni, M. (2005), Predecessors of the giant 1960 Chile earthquake, Nature, 437(7057), 404-407.

Delouis, B., Nocquet, J. M., and VAllee, M. (2010), Slip distribution of the February 27, $2010 \mathrm{Mw}=8.8$ Maule Earthquake, central Chile, from static and high-rate GPS, InSAR, and broadband teleseismic data, Geophys. Res. Lett., 37, 7.

Farias, M., Vargas, G., Tassara, A., Carretier, S., Baize, S., Melnick, D., and Bataille, K. (2010), Land-Level Changes Produced by the Mw 8.82010 Chilean Earthquake, Science, 329(5994), 916-916.

Fritz, H. M., Petroff, C. M., Catalan, P. A., Cienfuegos, R., Winckler, P., Kalligeris, N., Weiss, R., Barrientos, S. E., Meneses, G., Valderas-Bermejo, C., Ebeling, C., Papadopoulos, A., Contreras, M., Almar, R., Dominguez, J. C., and Synolakis, C. E. (2011), Field Survey of the 27 February 2010 Chile Tsunami, Pure Appl. Geophys., doi:10.1007/s00024-0001100283-00025.

FujII, Y., and SATAKe, K. (2007), Tsunami Source of the 2004 Sumatra-Andaman Earthquake inferred from Tide Gauge and Satellite Data, Bull. Seism. Soc. Am., 97(1A), S192-S207.

Hellmuth, A. S. C., Guillermo, V. C., and Guillermo, B. (1963), The seismic sea wave of 22 May 1960 along the Chilean coast, Bull. Seismol. Soc. Amer., 53(6), 1125-1190.
Imai, K., Namegaya, Y., Tsuji, Y., Funi, Y., Ando, R., Komatsubara, J., Komatsubara, T., Horikawa, H., Miyachi, Y., Matsuyama, M., YoshiI, T., Ishibe, T., Satake, K., Nishiyama, A., Harada, T., Shigihara, Y., Shigihara, Y., and Fujima, K. (2010), Field Survey for Tsunami Trace Height along the Coasts of the Kanto and Tokai districts from the 2010 Chile Earthquake, Journal of Japan Society of Civil Engineers, Ser. B2 (Coastal Engineering), 66(1), 1351-1355 (in Japanese with English abstract).

Imamura, F., Fujima, K., and Arikawa, T. (2010), Preliminary report of field survey on the 2010 tsunami in Chile, Journal of Japan Society for Natural Disaster Science, 29(1), 97-103 (in Japanese with English abstract).

KANAMORI, H. (1977), The Energy Release in Great Earthquakes, J. Geophys. Res., 82(20), 2981-2987.

Kanamori, H., and Anderson, D. L. (1975), Amplitude of earths free oscillations and long-period characteristics of earthquake source, J. Geophys. Res., 80(8), 1075-1078.

Kanamori, H., and Cipar, J. J. (1974), Focal process of the great Chilean earthquake May 22, 1960, Phys. Earth Planet. Inter., 9(2), 128-136.

Kato, T., Terada, Y., Nishimura, H., Nagai, T., and Koshimura, S. (2011), Tsunami records due to the 2010 Chile Earthquake observed by GPS buoys established along the Pacific coast of Japan, Earth Planets and Space, 63(6), E5-E8.

Lawson, C. L., and Hanson, R. J. (1974). Solving least squares problems, 340 pp., Prentice -Hall, Inc., Englewood Cliffs, N.J.

Lay, T., Ammon, C. J., Kanamori, H., Koper, K. D., Sufri, O., and Hutкo, A. R. (2010), Teleseismic inversion for rupture process of the 27 February 2010 Chile (M-w 8.8) earthquake, Geophys. Res. Lett., 37, 5.

LomNitz, C. (1970), Casualties and behavior of populations during earthquakes, Bull. Seismol. Soc. Amer., 60(4), 1309-1313.

Lorito, S., Romano, F., Atzori, S., Tong, X., Avallone, A., McCloskey, J., Cocco, M., Boschi, E., and Piatanesi, A. (2011), Limited overlap between the seismic gap and coseismic slip of the great 2010 Chile earthquake, Nature Geoscience, 4(3), 173-177.

Madariaga, R., Metois, M., Vigny, C., and Campos, J. (2010), Central Chile Finally Breaks, Science, 328(5975), 181-182.

Moreno, M. S., Bolte, J., Klotz, J., and Melnick, D. (2009), Impact of megathrust geometry on inversion of coseismic slip from geodetic data: Application to the 1960 Chile earthquake, Geophys. Res. Lett., 36, 5.

Окара, Y. (1985), Surface Deformation Due to Shear and Tensile Faults in a Half-Space, Bull. Seismol. Soc. Amer., 75(4), 1135-1154.

Plafker, G. (1972), Alaskan earthquake of 1964 and Chilean earthquake of 1960-Implications for arc tectonics, J. Geophys. Res., 77(5), 901-925.

Plafker, G., and Savage, J. (1970), Mechanism of the Chilean earthquake of May 21 and 22, 1960, Geol. Soc. Am. Bull., 81, 1001-1030.

Pulido, N., Yagi, Y., Kumagai, H., and Nishimura, N. (2011), Rupture process and coseismic deformations of the 27 February 2010 Maule earthquake, Chile, Earth Planets and Space, 63(8), 955-959.

SATAKE, K. (1988), Effects of bathymetry on tsunami propagationApplication of ray tracing to tsunamis, Pure Appl. Geophys., 126(1), 27-36. 
Satake, K. (1993), Depth distribution of coseismic slip along the Nankai trough, Japan, from joint inversion of geodetic and tsunami data, J. Geophys. Res., 98(B3), 4553-4565.

SAtAke, K. (1995), Linear and Nonlinear Computations of the 1992 Nicaragua Earthquake Tsunami, Pure Appl. Geophys., 144(3-4), 455-470.

Satake, K., Sakai, S. I., Kanazawa, T., Fujil, Y., Saito, T., and OzaKi, T. (2010), The February 2010 Chilean tsunami recorded on bottom pressure gauges, Abstract of Japan Geoscience Union Meeting 2010, MIS050-P005.

Tang, L., Titov, V. V., and Chamberlin, C. D. (2009), Development, testing, and applications of site-specific tsunami inundation models for real-time forecasting, J. Geophys. Res., 114, C12025, 12010.11029/12009JC005476.

TANiOKa, Y., and Satake, K. (1996), Tsunami generation by horizontal displacement of ocean bottom, Geophys. Res. Lett., 23(8), 861-864.

TichelaAr, B. W., and RuFf, L. J. (1989), How good are our best models? Jackknifing, Bootstrapping, and earthquake depth, Eos Trans. AGU, 70, 593, 605-606.

Tong, X. P., Sandwell, D., Luttrell, K., Brooks, B., Bevis, M., Shimada, M., Foster, J., Smalley, R., Parra, H., Soto, J. C. B., Blanco, M., Kendrick, E., Genrich, J., and Caccamise, D. J. (2010), The 2010 Maule, Chile earthquake: Downdip rupture limit revealed by space geodesy, Geophys. Res. Lett., 37.
Tsuji, Y., Ohtoshi, K., Nakano, S., Nishimura, Y., Fujima, K., Imamura, F., Kakinuma, T., NaKamura, Y., Imai, K., Goto, K., Namegaya, Y., Suzuki, S., Shirosita, H., and Matsuzaki, Y. (2010), Field Investigation on the 2010 Chilean Earthquake Tsunami along the Comprehensive Coastal Region in Japan, Journal of Japan Society of Civil Engineers, Ser. B2 (Coastal Engineering), 66(1), 1346-1350 (in Japanese with English abstract).

UNESCO/IOC (2010), 27 February 2010 Chile Erthquake and Tsunami Event-Post-Event Assessment of PTWS Performance, IOC Technical Series, 92.

Vigny, C., Socquet, A., Peyrat, S., Ruegg, J.-C., Metois, M., Madariaga, R., Morvan, S., Lancieri, M., Lacassin, R., Campos, J., Carrizo, D., Bejar-Pizarro, M., Barrientos, S., Armijo, R., Aranda, C., Valderas-Bermejo, M.-C., Ortega, I., Bondoux, F., Baize, S., Lyon-Caen, H., Pavez, A., Vilotte, J. P., Bevis, M., Brooks, B., Smalley, R., Parra, H., Baez, J.-C., Blanco, M., Cimbaro, S., and Kendrick, E. (2011), The 2010 Mw 8.8 Maule Megathrust Earthquake of Central Chile, Monitored by GPS, Science, 332, 1417-1421.

Watanabe, H. (1972), Statistical studies on the wave-form and maximum height of large tsunamis, J. Oceano. Soc. Japan, 28, 229-241.

Wessel, P., and Sмith, W. H. F. (1998), New, improved version of the Generic Mapping Tools released, EOS Trans. AGU, 79, 579. 